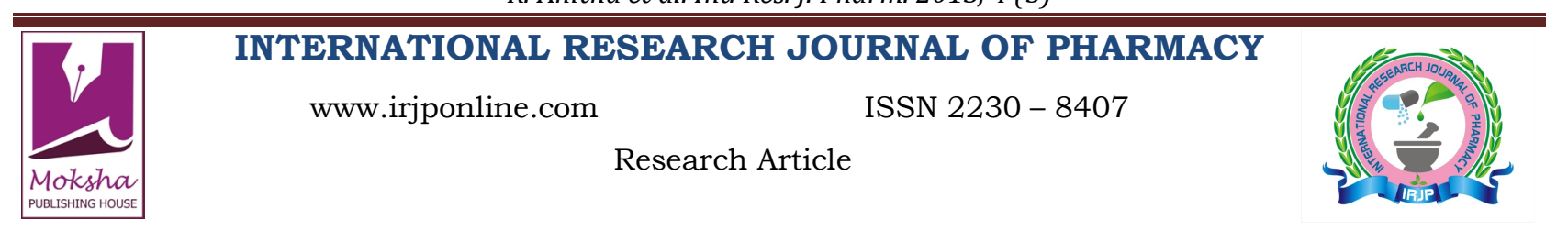

\title{
EVALUATION OF ANDROGRAPHIS PANICULATA (BURMF) WALL EX NEES, LEAF EXTRACTS AND ANDROGRAPHOLIDE ON GASTROINTESTINAL PATHOGENS
}

\author{
R. Anitha* and D. Raynukaa \\ Department of Plant Biology and Plant Biotechnology, Ethiraj College for Women, Ethiraj Salai, Egmore, Chennai, India \\ *Corresponding Author Email: anitha.rajasekaran023@gmail.com \\ Article Received on: 10/03/13 Revised on: 21/04/13 Approved for publication: 07/05/13
}

DOI: $10.7897 / 2230-8407.04547$

IRJP is an official publication of Moksha Publishing House. Website: www.mokshaph.com

(C) All rights reserved.

\begin{abstract}
Andrographis paniculata (BurmF) Wall Ex Nees called as Kalmegh or "King of Bitters is used in southeast Asia for treating several ailments. The aim of this study was to determine the antibacterial activity of Andrographis paniculata leaf extracts. The agar diffusion and micro-dilution methods were used to determine the antibacterial activity of the Petroleum ether and chloroform extracts. Chloroform and petroleum ether extracts inhibited Shigella, Proteus vulgaris, Klebsiella pneumonia and Salmonella paratyphi $A$ at concentration of 10 and $1 \mathrm{mg} / \mathrm{ml}$ respectively. The antibacterial property exhibited by the extracts were due to the presence of Andrographolide which was confirmed by HPLC analysis. Standard Andrographolide inhibited all bacterium except E.coli which indicates that it is a broad spectrum antibacterial compound. Although Andrographolide was effective against various gastrointestinal pathogens it does not have any harmful effect on the native flora.

Keywords: Antibacterial activity, Andrographis paniculata, Andrographolide.
\end{abstract}

\section{INTRODUCTION}

In the recent years, focus on the use of traditional medicine to treat human ailments has been revived all over the world. Medicinal plants used in traditional systems possess immense potentials. Andrographis paniculata (Burm.F) Wall Ex Nees (AP) also called Kalmegh or "King of Bitters" belongs to family Acanthaceae. It has been used for centuries in Asia to treat gastro-intestinal tract and upper respiratory infections, fever, herpes, sore throat, and a variety of other chronic infectious diseases. The Indian Pharmacopoeia literature indicates that it is a predominant constituent of at least 26 Ayurvedic formulations ${ }^{1}$. The entire herb possesses various activities like anthelmintic, alterative and tonic, hence used in treatment of dysentery, cholera, diabetes, influenza, bronchitis, swelling and itches ${ }^{2}$. The plant is also reported to possess hepatoprotectant and antioxidant properties ${ }^{3}$. A recent study has revealed that Andrographis paniculata has a broad spectrum of pharmacological effects such as antiinflammatory ${ }^{4}$, antiviral ${ }^{5}$, anti-malarial ${ }^{6}$, anticancer ${ }^{7-8}$ and immune stimulatory effects. The plant contains many important secondary metabolites such as diterpenoids. A number of diterpenoids and diterpenoid glycosides of similar carbon skeleton have been isolated from Andrographis, mainly the bitterest compounds. The leaves of Andrographis paniculata contain the highest amount of Andrographolide (2.39\%),the most medicinally active phytochemical in the plant, while the seeds contain the lowest ${ }^{10}$.Andrographolide has been isolated in pure form and it has shown various pharmacological activities like anti-platelet aggregation, antihyperglycemic, analgesic, antithrombotic, thrombolytic, antipyretic ${ }^{11}$ and antibacterial properties ${ }^{12}$. This study attempts to investigate the antibacterial effect of the petroleum ether, chloroform leaf extract and the standard Andrographolide on gastrointestinal pathogens like Shigella Sp., Proteus vulgaris, Klebsiella pneumoniae, Salmonella paratyphi $A$ and E.coli.

\section{MATERIALS AND METHODS}

\section{Extraction of Plant Material}

Healthy leaves of Andrographis paniculata were selected and dried. The dried leaves were ground and crushed into coarse powder. About $50 \mathrm{~g}$ of leaf powder was soaked in solvents such as chloroform and petroleum ether with twice its volume i.e (1:2) separately. The plant material was extracted thrice with the respective solvents and concentrated in a soxhlet apparatus.

\section{Antibacterial Assay}

Anti-bacterial screening was performed using agar diffusion assay. The crude extracts were dissolved in $10 \mu \mathrm{l}$ of DMSO and concentrations of $2,4,6,8,10 \mathrm{mg} / \mathrm{ml}$ of chloroform extract and $0.2,0.4,0.6,0.8,1.0 \mathrm{mg} / \mathrm{ml}$ of petroleum ether extract was prepared. Approximately $100 \mu \mathrm{l}$ of different concentration of the extract were loaded into the respective wells and incubated for $24 \mathrm{hrs}$ at $37^{\circ} \mathrm{C}$. Standard Andrographolide obtained from Dr. Pundarikakshudu, Avance phytotherapies, Ahmedabad, India; was used as standard and zone of inhibition was recorded.

\section{Minimum Inhibitory Concentration}

Minimum inhibitory concentration of the extracts were determined by dilution broth method in a 96 well microtitre plate concentration ranging from $5.5 \mathrm{mg}-6.4 \mathrm{mg} / \mathrm{ml}$ and $0.55 \mathrm{mg}-0.64 \mathrm{mg} / \mathrm{ml}$ for chloroform \& petroleum ether extracts that were diluted with nutrient broth. The bacterium was inoculated and incubated at $37{ }^{\circ} \mathrm{C}$ for $24 \mathrm{hrs}$. The growth of the bacterial culture was assessed by determining the optical density at $540 \mathrm{~nm}$.

\section{HPLC Analysis}

High performance liquid chromatography was performed to confirm the presence of Andrographolide in the petroleum ether extract. The chromatography was performed on C18 Shimadzu column $(4.6 \times 20 \mathrm{~mm})$. The metabolite was dissolved in methanol and $20 \mu \mathrm{l}$ was injected into the column. Mobile phase used was methanol with a flow rate of $1 \mathrm{ml} / \mathrm{min}$ 
and absorbance was determined at $245 \mathrm{~nm}$ using UV PDA

detector.

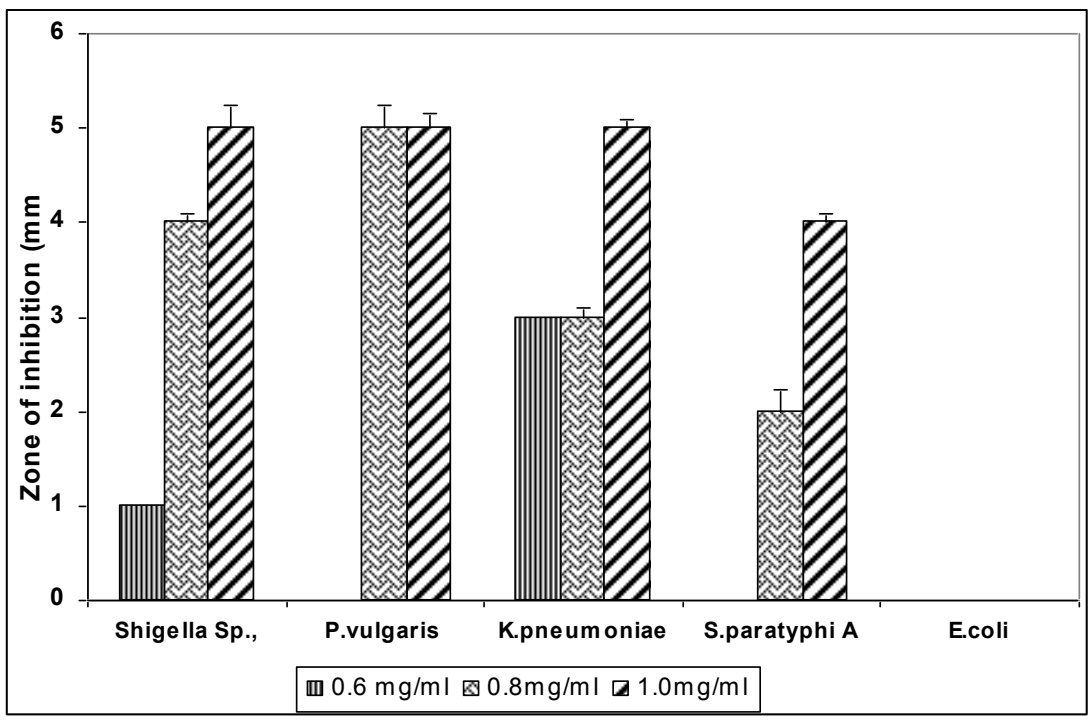

Figure 1: Effect of petroleum ether leaf extract of Andrographis paniculata on the bacterium. All values in triplicates

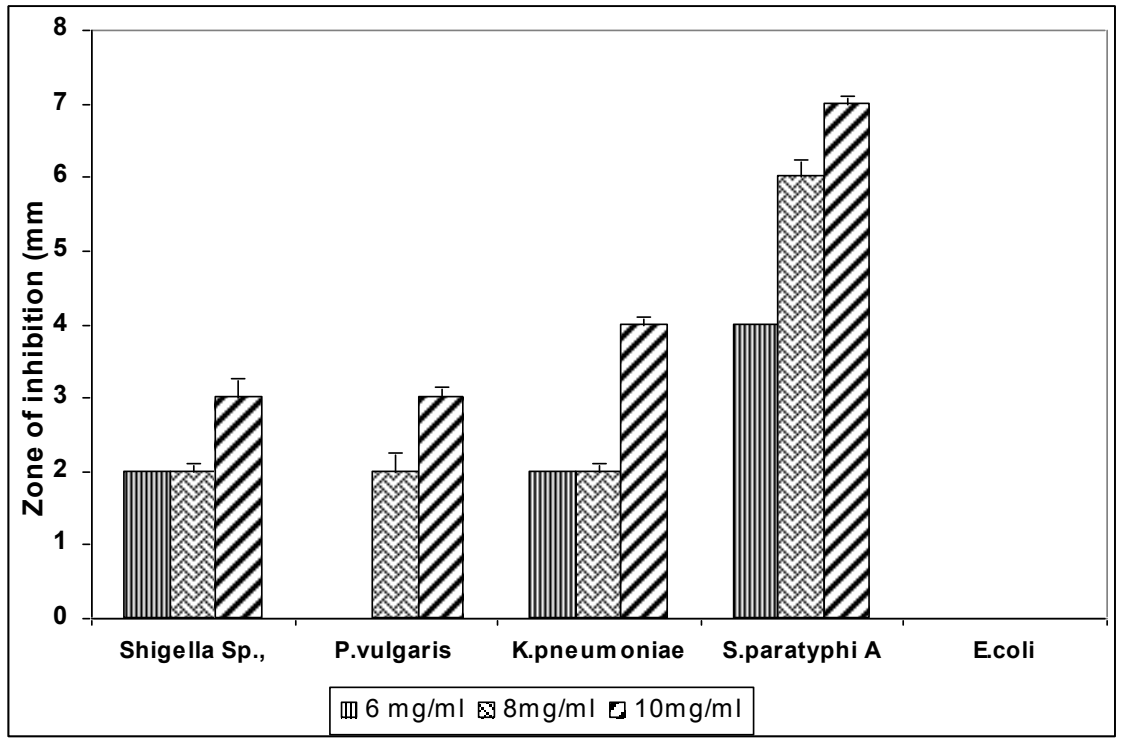

Figure 2: Effect of chloroform leaf extract of Andrographis paniculata on the bacterium. All values in triplicates 


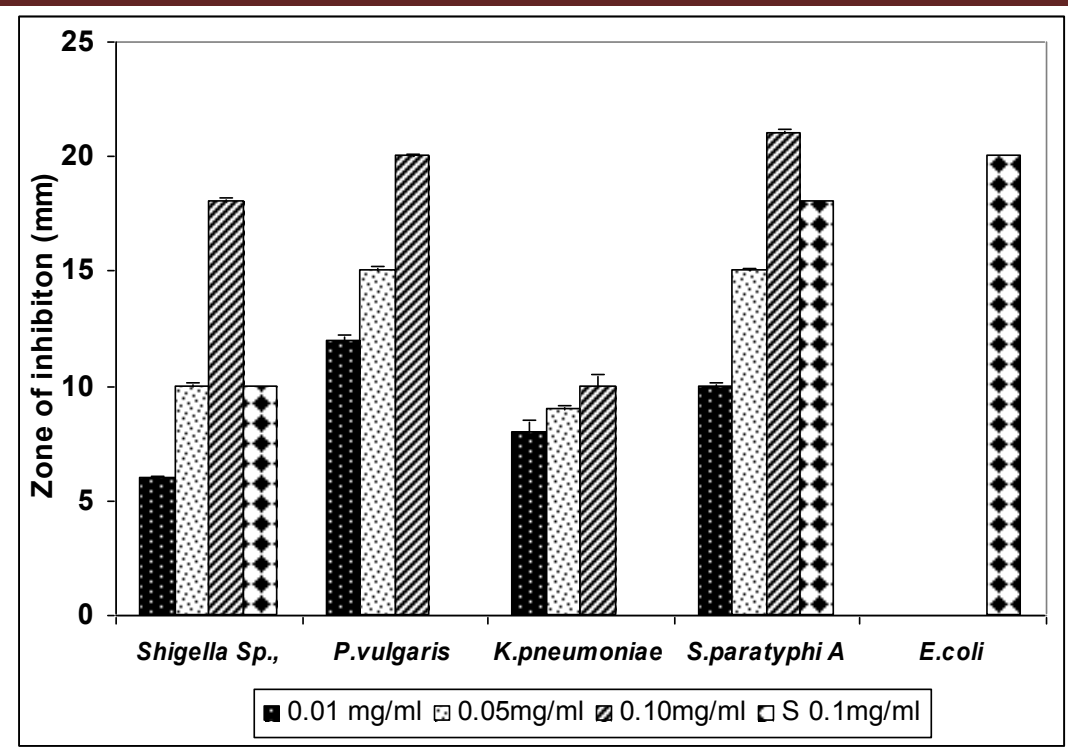

Figure 3: Effect of Andrographolide (100 $\mu \mathrm{g} / \mathrm{ml})$ on bacterium. All values in triplicates. S-Streptomycin (0.1 mg/ml)
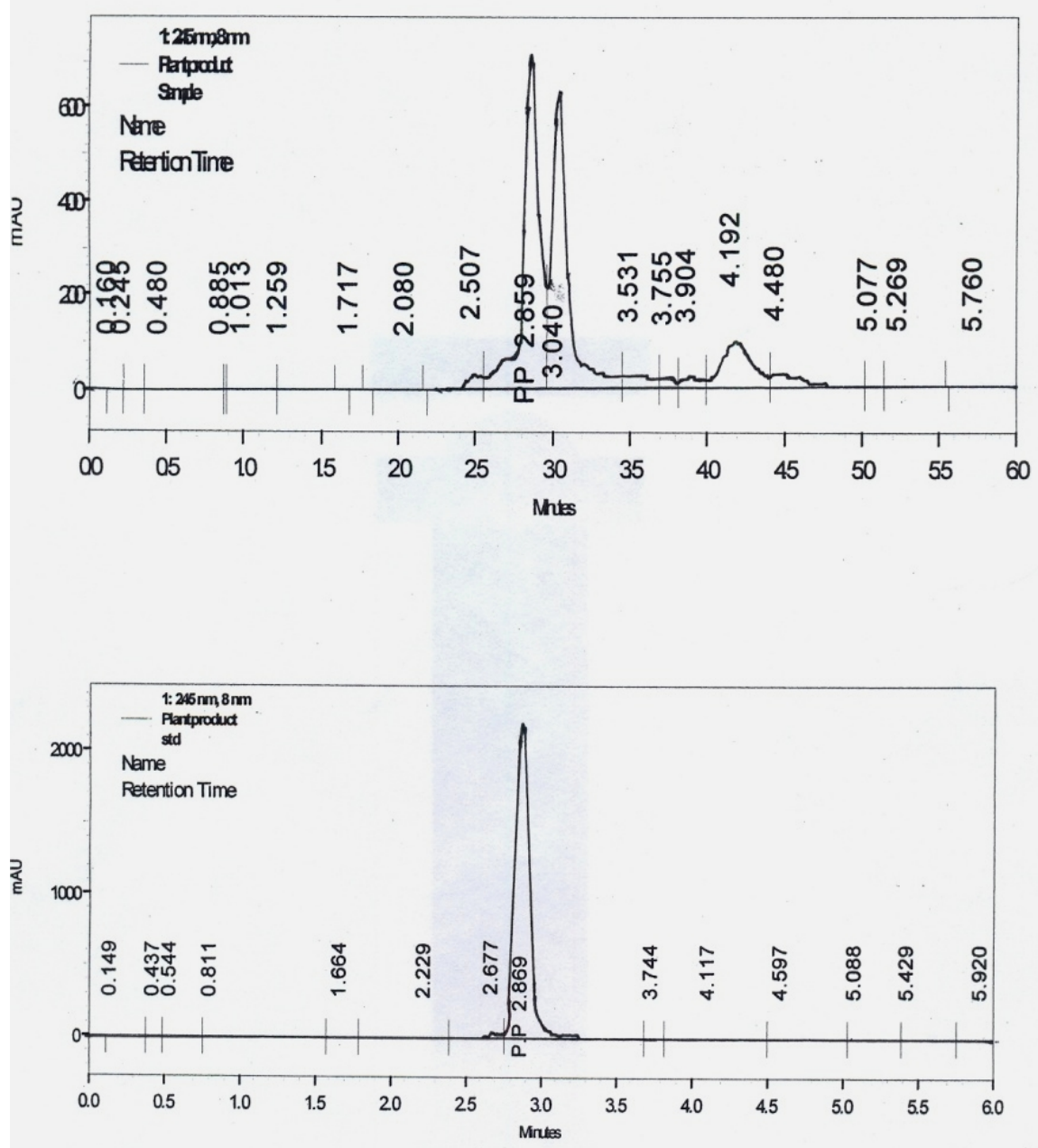

Figure 4: HPLC analysis of petroleum ether extract of $A$. paniculata with standard Andrographolide 


\section{RESULTS}

Screening for antibacterial activity of leaf extract of Andrographis paniculata revealed that petroleum ether extract inhibited Shigella Sp., Proteus vulgaris, Klebsiella pneumoniae with maximum inhibition zones being $5 \mathrm{~mm}$ at $1 \mathrm{mg} / \mathrm{ml}$ respectively. However, Salmonella paratyphi $A$ was inhibited with negligible difference in inhibition when compared to the other forms of bacteria. Klebsiella pneumoniae \& Salmonella paratyphi $A$ were not inhibited at a concentration of $1 \mathrm{mg} / \mathrm{ml}$ of chloroform extract. However at $10 \mathrm{mg} / \mathrm{ml}$, these two bacterial forms were inhibited maximum with inhibition zone of $6 \& 7 \mathrm{~mm}$ respectively. Chloroform extract was more efficient in inhibiting the bacteria than petroleum ether extract. However, such inhibition was obtained only at a huge concentration of $10 \mathrm{mg} / \mathrm{ml}$ (Figure 1 and 2). E.coli exhibited strong resistance to both the extracts. The MIC values for Salmonella Paratyphi A petroleum ether extract was $0.56-0.63 \mathrm{mg} / \mathrm{ml}$ and Klebsiella pneumoniae it was found to be between $5.8 \mathrm{mg} / \mathrm{ml}$ to $6.1 \mathrm{mg} / \mathrm{ml}$ in chloroform extract and in the case of petroleum ether extract, it was between $0.56-0.59 \mathrm{mg} / \mathrm{ml}$. Standard Andrographolide inhibited Proteus vulgaris, Klebsiella pneumoniae and Salmonella Paratyphi A effectively when compared to other bacterium, however no inhibition was recorded against E.coli (Figure 3). High performance liquid chromatography of the petroleum ether sample had a corresponding peak (Figure 4) as that of the standard and the peak was observed at $245 \mathrm{~nm}$ with a retention time of 3 minutes.

\section{DISCUSSION}

The anti-bacterial activity of Andrographolide proved that higher inhibition was obtained at a higher concentration of $100 \mu \mathrm{g} / \mathrm{ml}$ in case of all 4 tested organisms. However, inhibition was also observed at a lower concentration of 10 and $50 \mu \mathrm{g} / \mathrm{ml}$. However, the absence of antibacterial activity of Andrographis paniculata extracts or Andrographolide on Salmonella typhimurium, E.coli, Shigella sonnei, Staphylococcus aureus, Pseudomonas aeruginosa, Streptococcus pneumoniae even at concentration of 100, 10 and $1 \mathrm{mg} / \mathrm{ml}$ was reported earlier ${ }^{13 .}$ The present study revealed that the leaf extract was ineffective on E.coli alone. It is evident from the repeated work that aqueous extracts of Andrographis paniculata did not possess the active principle components which exhibited antibacterial activity. However the petroleum ether \& chloroform extract showed an appreciable inhibitory activity. Minimum inhibitory concentration was determined \& inferred that the minimum inhibitory concentration for Salmonella Paratyphi $A$ in chloroform extract was between $5.8-6.0 \mathrm{mg} / \mathrm{ml}$ and in petroleum ether extract was between $0.56-0.63 \mathrm{mg} / \mathrm{ml}$. Similarly, the minimum inhibitory concentration for Klebsiella pneumoniae was found to be between $5.8 \mathrm{mg} / \mathrm{ml}$ to $6.1 \mathrm{mg} / \mathrm{ml}$ in chloroform extract and in the case of petroleum ether extract, it was between $0.56-0.59 \mathrm{mg} / \mathrm{ml}$. It is evident that Andrographolide in the petroleum ether extract exhibited antibacterial effect on the test bacterium.

\section{CONCLUSION}

From the above results it is evident that the antibacterial activity of petroleum ether extract can be solely attributed to the presence of Andrographolide which seems to exhibit profound antibacterial activity on the gastrointestinal pathogens and is safe on E.coli at the tested concentration.

\section{ACKNOWLEDGEMENT}

The authors thank the Principal and head of the Department, for providing the laboratory facility. We are deeply indebted to Dr.Pundarikakshudu, Avance Phytotherapies, Ahmedabad, India for providing the standard Andrographolide and Mrs. Jamuna sivasankaran, Scientist, Forensic Science Department, Government of Tamilnadu for carrying out HPLC analysis.

\section{REFERENCES}

1. Iruretagoyena MI, Tobar JA, Gonzalez PA, Sepulveda SE, Figueroa CA, Burgos RA, Hanche JL and Kalergis AM. Andrographolide interferes with $\mathrm{T}$ cell activation and reduces experimental auto immune encephalomyelitis in mouse. J. Pharmacol.Exp.Ther, 2005; 12: 366-372.

2. Poolsup N, Suthisisang C, Prathanturang S, Asawamekiss A \& Chanchareon U. Andrographis paniculata in the symptomatic treatment of uncomplicated upper respiratory tract infection: systematic review of randomized controlled trials. Journal of clinical \& pharmaceutical therapy, 2004;29:37-45.http://dx.doi.org/10.1046/j.1365-2710.200 3.00534.x PMid: 14748896

3. Trivedi NP, Rawal UM. Hepatoprotective \& antioxidant property of Andrographis paniculata Nees in BHC induced liver damage in mice. Indian journal of experimental biology, 2000; 39(1): 41-46.

4. Sheeja K, Shihab PK and Kuttan G. Antioxidant and anti-inflammatory activities of the plant Andrographis paniculata Nees. Immunopharmacol. immunotoxicol, 2006; 28: 129-140. http://dx.doi.org/ 10.1080/ 08923970600626007 PMid:16684672

5. Sharma A, Krishan L and Handa SS. Standardization of the Indian crude drug Kalmegh by high pressure liquid chromatographic determination of andrographolide. Phytochem.Anal, 1992; 3: 129-31. http://dx.doi.org $/ 10.1002 /$ pca. 2800030308

6. Misra P, Pal NL, Guru PY, Kathiyar JC, Srivastava V and Tandon JC. Antimalarial activity of Andrographis paniculata (Kalmegh) against Plasmodium berghei NK65 in Mastomys natalensis. Int. J.of.Pharmacognosy, 1992; 30: 263-274.

7. Sukardiman H, Widyawaruyanti A, Sismindari and Zaini NC. Apoptosis inducing effect of Andrographolide on TD-47, Human breast cancer cell lines. African .J.Traditional complementary and Alternative medicine, 2007; 4: 345-351.

8. Zhou J, Zhang S, Ong C and Shen H. Critical role of proapoptotic Bcl-2 family member in Andrographolide induced apoptosis in human cancer cell. Biochem.Pharmacol. 2006; 72:132-144. http://dx.doi.org/10.1016 j.bcp.2006.04.019 PMid:16740251

9. K Siddhartha, Mishra Neelam, Sangwan S and Sangwan Rajender. Andrographis paniculata (Kalmegh): A Review.; Pharmacognosy Reviews.2007; 1(2): 283-298.

10. Wiart C, Kumar K, Yusof M, Hamimah H, Fauzi. MY and. Sulaiman M. Antiviral property of ent-labdene diterpene of Andrographis paniculata Nees, inhibitor of Herpes simplex virus type-I.; Phytother.Res, 2005; 19 : 1069-1070. http://dx.doi.org/10.1002/ptr.1765 PMid:16372376

11. Yu BC, Hung CR, Chen WC, Cheng JT. Antihyperglycemic effect of andrographolide in streptozotocin-induced diabetic rats. Planta med, 2003; 69: 1075-1079. http://dx.doi.org/10.1055/s-2003-45185 PMid: 14750020

12. Kuyal P, Tiwari UK, Shukla A, Gaur AK. Chemical constituents isolated from Andrgraphis paniculata. Indian.J. of Chem, 2010; 49 B: 356-359.

13. Youhong XU, Raymond L, Marshall. An investigation on the antimicrobial activity of Andrographis paniculata extracts \& Andrographolide in vitro. Asian journal of plant sciences. 2006; 5(3): 529-530.

Cite this article as:

R. Anitha and D. Raynukaa. Evaluation of Andrographis paniculata (Burmf) Wall ex Nees, leaf extracts and andrographolide on gastrointestinal pathogens. Int. Res. J. Pharm. 2013; 4(5):222-225 